\title{
International Constitutional Law and Judicial Review of Domestic Human Rights Legislation
}

\begin{tabular}{|c|c|}
\hline Journal: & Vienna Journal on International Constitutional Law \\
\hline Manuscript ID & Draft \\
\hline Manuscript Type: & research-article \\
\hline Classifications: & Comparative Constitutional Law, Human Rights, Rule of Law \\
\hline Keywords: & $\begin{array}{l}\text { International Constitutional Law, Le contrôle de conventionnalité des lois, } \\
\text { Judicial Review, International Human Rights }\end{array}$ \\
\hline Abstract: & $\begin{array}{l}\text { This article discusses the idea of international human rights law as } \\
\text { 'constitutional law'. It applies the French concept of Le contrôle de } \\
\text { conventionnalité des lois, to demonstrate the constitutional potentials of } \\
\text { international human rights law in the domestic sphere. In most monist } \\
\text { constitutional systems based on the French civilian model, international law } \\
\text { takes precedence over acts of parliament and other domestic legislation. } \\
\text { Due in part to that hierarchy, conventionnalité permits the courts to review } \\
\text { domestic law for compatibility with international law. From that } \\
\text { perspective, international human rights norms can be said to have } \\
\text { assumed a 'para-constitutional' function. Using two case studies from } \\
\text { francophone Africa, this article argues that, conventionnalité has the } \\
\text { potential to play a significant role in the domestic implementation of } \\
\text { international human rights and ultimately contributing to a more } \\
\text { comprehensive domestic human rights regime. }\end{array}$ \\
\hline
\end{tabular}




\section{Introduction}

International law and in particular, international human rights law has had a substantive influence on domestic legal systems. This has been due in part to the role of national judges in applying international law and the constitutional position of international law within the national legal order. National jurisdictions have varied in their application of international law, from acting as 'worldly judges' who readily embrace international law to those that strenuously seek to preserve national sovereignty.

Recent scholarship on international human rights has shown a growing fascination with the idea that it possesses constitutional qualities. Whilst research on the domestic application of international human rights abound, these bear no direct relationship with the idea of international human rights as international constitutional law. Yet, there is need to relate that analogy to specific methods or techniques applied by national jurisdictions to give international human rights law a 'constitutional' character. That analysis deserves some attention not least to enrich comparative law, but also given the growing reliance of domestic courts on international law. Moreover, due to increasing regional integration and globalisation, there is need for more persuasive mechanisms for giving international law (especially human rights) greater effect within the national legal order. This article attempts to draw that analogy by examining the French practice of $L e$ contrôle de conventionnalité des lois as one that has potential to give international human rights that para-constitutional function at the domestic level. It discusses the role of international human rights as a form of 'constitutional law' with the potential to contribute to the consistency of domestic human rights legislation. In most monist constitutional orders, international norms, including human rights norms take precedence over acts of parliament and other domestic legislation. The necessary implication is that, domestic legislation has to be compatible with international law. This is particularly so of constitutional systems that are based on the French civilian model. The importance of this hierarchy of norms is all the more significant in jurisdictions where the constitutional system does not allow for post legislative judicial review. In those systems, conventionnalité allows the courts to review domestic law for compatibility with 
international (human rights) law. In this way, international human rights norms can assume a 'para-constitutional' function by acting as a standard for judicial review.

This article adopts a comparative approach to examine two case studies in Francophone Africa - Cameroon and Senegal. An assessment of the practice in Cameroon shows a reticence of the lower courts towards the application of international human rights law in a way that indicates they are engaging with conventionnalité. Whereas, the Supreme Court in a recent decision, has laid down a precedent, which may be indicative of the amenability of the courts to embracing that practice. In contrast, the approach of the Senegalese courts is characterised by judicial antipathy and aversion towards international law. Both the superior and lower jurisdictions have shown awareness of the constitutional supremacy of international law. Nevertheless, the approach has been a conscious avoidance to apply it in a way that affirms its supremacy over national legislation. Notwithstanding the perceived difficulties, this article argues that conventionnalité has an important role to play in respect of enhancing the domestic protection of human rights in Cameroon and Senegal, especially with respect to rights that are under-protected domestically or for which no provision has been made. The wider significance of this analysis is that, it may assist in the dissemination of constitutional practices unknown or neglected within national jurisdictions.

After this introduction, the article proceeds as follows. Section two examines the idea of international human rights as international constitutional law. Section three analyses the role of conventionnalité in respect of international human rights law. In section four, the focus is on examining Cameroon and Senegal to demonstrate the practical application of conventionnalité and it's potential in according international human rights a 'paraconstitutional' function. The conclusion is contained in the last section.

\section{International Human Rights Law as International Constitutional Law}

The reference to constitutional law as a concept applicable to discourse on international law is something that continues to polarise debates amongst constitutionalists and 
internationalists. ${ }^{1}$ The differences in opinion stemming primarily from the incongruity of applying in the international sphere, what was traditionally a term limited to the domestic sphere. That has been particularly aggravated by a lack of terminological consistency. In this section, the paper turns to a focus on identifying international human rights law as an aspect of constitutional law principally by emphasising its constraining features on domestic governments and regulating the relationship between the government and citizens, as functions of a constitutional system. That is important in terms of shaping the relationship between domestic human rights and international human rights and establishing the continued rationale for the coexistence of the two systems.

\subsection{What is International Constitutional Law?}

In order to more clearly address the claim that international human rights can be understood as international constitutional law, it may be helpful first to clarify what constitutional law embodies. Rather than add to the terminological ambiguities, I adopt an approach that endeavours to capture the essence of what constitutional law is and how that can be applied within international law discourse. It is no doubt influenced by constitutional ideology and practices developed at the domestic level. The approach proceeds on the basic assumption that a constitution, in its normative sense refers to the cumulation of the fundamental legal norms which regulate the social and political life of a polity and in particular delineates the parameters for the exercise of public authority. ${ }^{2}$ That idea of a constitution is both normative and substantive in the sense that it provides the basic rules of the polity on issues such as law making and enforcement and

\footnotetext{
${ }^{1}$ Christian Walter, 'Constitutionalising (Inter)national Constitutional Law' 44(2001) German Yearbook of International Law 170, 191; Neil Walker, 'Post National Constitutionalism and the Problem of Translation' in J.H.H Weiler \& M. Wind (eds) European Constitutionalism Beyond the State (CUP 2003) 27, Peters, 'Compensatory Constitutionalism: The Function and Potential of Fundamental International Norms and Structures' 19(2006) Leiden Journal of International Law 579-610, 581; Bardo Fassbender, 'The Meaning of International Constitutional Law' in Ronald MacDonald \& Douglas Johnston (eds) Towards World Constitutionalism: issues in the Legal Ordering of the World Community (2005 Martinus Nijhoff Publishers) 837-852, 838.

2 Anne Peters \& Klaus Armingeon, ' Introduction- global Constitutionalism from an Interdisciplinary Perspective' 16(2)(2009) Indiana Journal of Global Studies 385-395, 387; Peters, 'Compensatory Constitutionalism' 581; Fassbender, 'The Meaning of International Constitutional Law' 838; Konrad Lachmayer, 'The International Constitutional Law Approach' 1(2) (2007) ICL Journal (www.icljournal.com) 91-99, 94-95.
} 
fundamental principles such as judicial independence, rule of law, democracy and human rights. Some of the principles can be identified in some aspects of the international community (inclusive of states, their subjects and international organisations). From that perspective, there are constitutions both at the domestic level and the international level. At the international level, there are several autonomous communities or legal systems each governed by its specific fundamental substantive rules. ${ }^{3}$ To the extent that the rules reflect the essence of a constitution defined above, they form the constitution of that community. In that respect, there is not one but several constitutions regulating different international communities as there would be several constitutions regulating different domestic communities (individual countries). ${ }^{4}$ For instance, it has been argued that to the extent that international or regional organisations can be considered legal systems, it is possible to identify aspects of their fundamental rules which form their constitution. ${ }^{5}$ The European Union is often regarded as a legal system with recognised features of a constitutional system. ${ }^{6}$

It is within the above context that international constitutional law should be understood. It is the term that identifies all the different constitutional systems and describes their interdependencies. ${ }^{7}$ Anne Peters for instance describes international constitutional law as consisting of the 'bulk of the most important norms which regulate political activity and relationships in the global polity'. ${ }^{8}$ In other words, it consists of a subset of international rules and principles with particular importance such that they deserve to be identified as having a constitutional character. ${ }^{9}$ These norms are not necessarily embodied in a single document, but are reflected in treaties, soft law and custom. ${ }^{10}$ This resonates with a definition proposed by Bardo Fassbender which regards international constitutional law

\footnotetext{
${ }^{3}$ Lachmayer, 'The International Constitutional Law Approach' 94-95.

${ }^{4}$ Lachmayer, 'The International Constitutional Law Approach' 96-97.

5 Lachmayer, 'The International Constitutional Law Approach' 96-97.

${ }^{6}$ Neil Walker, 'Reframing EU Constitutionalism' in J. Dunoff \& J. Tratchman (eds) Ruling the World: Constitutionalism, International Law and Global Governance (CUP 2009)162-176; Lachmayer, 'The International Constitutional Law Approach' 96-97.

${ }^{7}$ Lachmayer, 'The International Constitutional Law Approach' 98.

${ }^{8}$ Peters, ‘Compensatory Constitutionalism' 582.

${ }^{9}$ ibid

10 Peters \& Armingeon, 'Introduction- global Constitutionalism' 387.That reflects the nature of the 'unwritteness' of the UK Constitution which is embodied in different legal documents.
} 

as embodying formal and substantive rules of international law distinguished by their fundamental character. ${ }^{11}$ It is in that light that, arguably, the international human rights system is increasingly regarded as a legal system with a constitutional character.

\subsection{International Constitutional Law and Human Rights}

From the perspective of domestic constitutional law, certain features need to be identified in order for a document to be regarded as a constitution. For instance, it should be a written document. However, that proposition may be rebutted with reference to an established constitutional system such as the United Kingdom which has no written constitution. The international human rights systems consists of fundamental norms captured in different written agreements such as the covenants and the conventions dealing with different aspects of human rights (social, economic, civil, political, gender equality and disability rights). The understanding of international constitutional law as demonstrated earlier would subsume these fundamental norms under the umbrella term of constitutional law.

Admittedly, that is a simplistic argument to make in the sense that, there are other features attributed to domestic constitutional law which should be taken into account when transposing that concept into the international context. Thus additionally, constitutional law is the result of a 'constitutional' moment and made by an identified constituent power. ${ }^{12}$ It should set up a governmental system, define its members and create a hierarchy of norms. ${ }^{13}$ Some of these are much more problematic to identify in the context of international human rights. For instance, although there has been a proliferation of human rights instruments post 1945, there is not a single moment where there was a 'big bang' that could be considered a constitutional moment. Moreover, there is not one source of international human rights law. There are several regimes both

\footnotetext{
${ }^{11}$ Fassbender, 'The Meaning of International Constitutional Law' 838.

${ }^{12}$ Stephen Gardbaum, 'Human Rights and International Constitutionalism' in Dunoff \& Trachtman supra, 238-239.

${ }^{13}$ These features have been applied in the arguments identifying the United Nations Charter as the constitution of the international community. See R MacDonald, 'The Charter of the United Nations in a Constitutional Perspective' 20(1999) Australian Yearbook of International Law 205; Fassbender, 'The United Nations Charter as a Constitution of the International Community' 36(1997-1998) Columbia Journal of Transnational law 529.
} 
international and regional. In addition, some fundamental human rights developed from custom and general principles even if they eventually are incorporated into treaties. ${ }^{14}$ Some of these difficulties could be addressed by a closer examination of specific human rights systems. The adoption of the OAU Charter in 1963 (and subsequently the African Union) can be considered a process which led to that constitutional moment reflecting a shift from colonialism to a desire to establish national sovereignty, self-governance and respect for human dignity. The adoption of the African Charter on Human and Peoples' Rights in 1981 is a demonstration of that commitment to the respect for human dignity. Thus, constitutional law as understood here would embrace the fact that different legal regimes may have different periods of constitutional moments reflecting their specific development.

Perhaps the more problematic feature is that of hierarchy of norms within the international human rights system, particularly in the light of the fact that there is no single source of international human rights law. Nevertheless, some international human rights norms regarded as the critical core of human rights have achieved higher law status as binding treaty makers and possibly assuming supremacy over conflicting custom. ${ }^{15}$ Such human rights norms can be deemed as 'supra positive' in the sense that they act as constrains on the production of other international law. ${ }^{16}$ Some jus cogens norms such as the prohibition of torture would fall within that category. Further, norms from other legal systems tend to impose some kind of supremacy over ordinary international law. An example is the European Convention on Human Rights which in respect of member states, is regarded as superior to other treaty obligations. ${ }^{17}$

The above difficulties notwithstanding, there is something inherently constitutional about international human rights law, to the extent that it regulates the relationship between governments and those who are governed and defines the contours of legitimate

\footnotetext{
${ }^{14}$ Gardbaum, 'Human Rights and International Constitutionalism' 240.

${ }^{15}$ Gardbaum, 'Human Rights and International Constitutionalism' 241.

${ }^{16}$ Jeffrey Dunoff and Joel Trachtman, 'A Functional Approach to International Constitutionalisation' in Dunoff \& Trachtman (eds) Ruling the World, 11; Gardbaum, 'Human Rights and International Constitutionalism' 241.

${ }^{17}$ See for instance, Bosphorus Hava Yollari Turizm Ve Ticaret Anonim Sirketi v. Ireland, App No 45036/98, ECHR 2005-VI. See also Gabaum, Human Rights and International Constitutionalism' 242.
} 
government actions with respect to persons within their jurisdiction. ${ }^{18}$ Thus, human rights are a set of fundamental norms that impose obligations on the government. The obligations are both positive and negative. In other words, on the one hand, governmental institutions are under an obligation to provide the necessary conditions for the effective enforcement of fundamental human rights norms. For instance, the obligation under article 1 of the African Charter on Human and Peoples' Rights for states to take legislative or other measures to give effect to the rights recognised in the Charter. ${ }^{19}$ On the other hand, states are bound to refrain from acting in ways that undermine their human rights obligations. The Convention against Torture, prohibits any derogation from its provisions even in exceptional times. ${ }^{20}$ Similarly, under the United Nations Charter, article 1, paragraphs 3 and 55, all member states have accepted to be bound by the obligation to promote respect for human rights. Thus by signing the UN covenants and other human rights instruments, members are bound to give effect to those obligations in the domestic context. Further, the individuals protected by international human rights law have been given further powers or platforms to vindicate their rights beyond the national territories through the creation of human rights courts which enforce specific treaty obligations.

Moreover, human rights are regarded as a fundamental aspect of a domestic constitutional system and increasingly, constitutional systems devoid of the protection of human rights are considered illegitimate systems. ${ }^{21}$ Thus, as asserted by Gardbaum, if there is an international constitutional system, international human rights must be a part of that system. ${ }^{22}$

The above view of international human rights as international constitutional law is relevant to the domestic setting with respect to the fact that it places limits on government

\footnotetext{
18 Gardbaum, 'Human Rights and International Constitutionalism' 238; Peters, 'Compensatory Constitutionalism' 599.

${ }^{19}$ African Charter on Human and Peoples' Rights, 1 OAU Doc. CAB/Leg/67/3/Rev.5 (1981), art. 1.

${ }^{20}$ Convention against Torture and Other Cruel, Inhuman or Degrading Treatment or Punishment, GA res. 39/46, annex, 39 UN GAOR Supp. (No. 51) at 197, UN Doc. A/39/51 (1984); 1465 UNTS 85, art. 2(2).

${ }^{21}$ Peters, 'Globalisation of State Constitutions' 256.

${ }^{22}$ Gardbaum, 'Human Rights and International Constitutionalism' 240
} 
actions in their interaction with persons within their jurisdiction. The significance of the 'constitutional' element here is that the governments are not expected to choose the rights which they intend to enforce but are compelled by their international commitment to enforce all rights. Of course it could be argued that the presence of domestic bills of rights or other forms of recognition of human rights make the presence of international human rights superfluous especially if a state chooses to prioritise domestic over international human rights. Yet, the significance of the latter can be more poignant in situations where specific human rights are under-enforced or not recognised or protected at all under domestic law. In such situations, international human rights as international constitutional law may fill that gap, thereby acting as a form of supplemental constitution. Domestic and international human rights could then be seen as working in tandem to provide a comprehensive system for the protection of human rights. Even within systems where under-protection may not be an issue, international human rights retain substantial significance. With increasing globalisation and development and recognition of new rights, international human rights help to enhance domestic recognition and protection of such rights ensuring the comprehensiveness of the domestic system. The next section examines the practice of conventionnalité as an approach to establishing a comprehensive human rights regime domestically, by according international human rights a more prominent role at the domestic level.

\section{Conventionnalité, International Human Rights and the Domestic Legal Order}

The practice of le contrôle de conventionnalité des lois is a practice with the potential to create a distinct harmony between international human rights and domestic human rights law. This is not only significant due to the perceived harmony in the legal system, but from a human rights perspective, it expands the range of rights that are available domestically even if their origin is external. To fully understand the concept and its potential in human rights enhancement, the development of the concept would be explored briefly, followed by an analysis of its potential contribution to domestic human rights. 


\subsection{Le contrôle de conventionnalité des lois}

In the French constitutional system, traditionally, no court was empowered to review the constitutionality of laws after they had been enacted. ${ }^{23}$ That aversion was grounded principally on the notion of legislative supremacy a product of the French Revolution. ${ }^{24}$ Due to the atrocities to which citizens had been subjected by the parlements in the Ancien Regime, a major goal of the French Revolution was to restore sovereignty with the people and maintain a separation of powers (à la Montesquieu) between the three branches of government. ${ }^{25}$ Sovereignty was exercised through the elected representatives. The Conseil Constitutionnel was created in 1958 to resolve disputes relating to separation of powers between the legislature and the executive, to ensure the legislature did not encroach on the legislative domain of the executive. ${ }^{26}$ Again laws could not be challenged once they had been promulgated because these laws which were considered sacrosanct had been voted for by the elected representatives on behalf of the sovereign majority. ${ }^{27}$ Judicial review of legislation already in force was regarded as 'undemocratic' and likely to orchestrate chaos and imbalance in the separation of powers. ${ }^{28}$

The absence of post -legislative review created a vacuum in the constitutional order which was later partially filled by the practice of reviewing the compatibility of national legislation with international treaties. The basis of that practice is article 55 of the French Constitution which states the primacy of international treaties over national legislation. It provides that, duly ratified international instruments once promulgated take precedence over national laws, provided the other party implements the same. That provision has been interpreted by the courts to imply that, having been accorded a 'primacy' status, all

\footnotetext{
${ }^{23}$ Louis Favoreu, 'La Légitimité du Juge Constitutionnel' (1994) 2 Revue Internationale de Droit Comparé $557,558$.

${ }^{24}$ Mauro Cappelletti, The Judicial Process in Comparative Perspective (Oxford University Press 1989) 153; Martin Rogolf, 'A Comparison of Constitutionalism in France and the United States' (1997) 49 Maine Law Review 21.

${ }^{25}$ The parlements attributed to themselves the power to review legislation, a power which was exercised in abusive and unpopular manner, fostering inequality and preventing proposed reforms intended for the benefit of the citizens. See Cappelletti (n 24) 153. See also Bailey Stone, The French Parlements and the Crisis of the Old Regime (University of North Carolina Press 1986) 3-15.

${ }^{26}$ Sweet, The Birth of Judicial Politics in France 47.

27 Jean Gicquel \& Jean-Éric Gicquel, Droit Constitutionnel et Institutions Politiques $\left(24^{\text {th }}\right.$ ed, Montchrestien 2010) 200.

${ }^{28}$ Gicquel \& Gicquel, Droit Constitutionnel 200.
} 
other legislation must be subordinate to international treaties and therefore must conform with them. ${ }^{29}$

The development of conventionnalité was given a boost by the Conseil Constitutionnel (France's Constitutional Court) which is empowered to rule on the constitutionality of laws prior to their promulgation. It declined in 1975 to rule on the compatibility of national legislation with an international treaty. ${ }^{30}$ The Conseil Constitutionnel held that, it was not competent to examine the conformity of national law (the law relating to abortion) with France's international engagements, in this case, the European Convention on Human Right (ECHR). The Conseil Constitutionnel held in later decisions ${ }^{31}$ that the control of conformity with international treaties had to be exercised by the ordinary jurisdictions - the Cour de Cassation and the Conseil d'Etat (France's supreme ordinary and administrative jurisdictions respectively). The Cour de Cassation took that in its stride in Société des Cafés Jacques Vabre ${ }^{32}$ where it declined to apply section 265 of the Custom Code of 1966 on the basis of incompatibility with article 95 of the Treaty of Rome. ${ }^{33}$ In reliance on article 55 of the French Constitution, the Cour reasoned that, the legislator intended to give precedence to the Treaty. ${ }^{34}$ It followed that, the Custom Code though enacted after the Treaty, could not be applied due to its incompatibility. ${ }^{35}$ The Conseil d'État ${ }^{36}$ subsequently followed that position in the Nicolo case to review a legislative provision for compatibility with the Treaty of Rome. ${ }^{37}$ Although those initial cases were reviewed on the basis of the Treaty of Rome, the jurisprudence of the courts has developed to include other international instruments ${ }^{38}$ notably the ECHR. ${ }^{39}$

\footnotetext{
${ }^{29}$ See discussion below.

${ }^{30}$ Decision No. 74-54 DC du 15 Janvier 1975, Recueil p. 19.

${ }^{31}$ Decision No. 86-216 DC du 3 Septembre 1986, Recueil p. 135, Decision No. 89-268 du 29 Décembre 1989, Recueil p. 110.

${ }^{32}$ Syndicat Général des Ingénieurs-conseils \& Administration des Douanes v. Société des Cafés Jacques Vabre, Judgment of 24 May 1975, CC(chamber mixte), 1975, D.S. Jur, (Fr) 497.

${ }^{33}$ Treaty of Rome 1957, establishing the European Economic Community.

${ }^{34}$ Cafés Jacques Vabre (n...).

${ }^{35}$ ibid.

${ }^{36}$ France's supreme appellate administrative court.

${ }^{37}$ CE, Ass. 20 October 1989, Nicolo, Rec. Lebon, 190.

${ }^{38}$ Hunter-Henin, 'Constitutional Developments and Human Rights in France' 171.

${ }^{39}$ See for instance CE, 1991, M. Belgacem et Mme Babas; CE Ass., 2007, Gardedieu.
} 
Conventionnalité is exercised 'par voie d'exception' which implies that, a party to a matter before a court can raise the issue of the compatibility of a national legislation affecting them, with an international treaty and may object to its application. The substantive matter is suspended for the court to determine the issue of compatibility. If the impugned law is found to be incompatible, the court would refuse to apply it. However, the application of article 55 is subject to the treaty following the appropriate channels of ratification, publication in the official gazette and reciprocity. Nevertheless, with respect to human rights treaties, the condition of reciprocity may be dispensed with. $^{40}$

\subsection{Conventionnalité and the Para-constitutional Function of International Human Rights Law}

Having noted above the features of conventionnalité, this subsection explores its role in defining the relationship between domestic human rights and international human rights. It could be argued that, conventionnalité has the functional attribute of ascribing international human rights a para-constitutional function. That proposition is explained further below.

Even though as discussed earlier, international human rights law may be considered as 'constitutional law', its implementation at the domestic level is not axiomatic. Domestic implementation is dependent on a number of factors including a state's constitutional architecture, whether influenced by monism or dualism. Even within these monist and dualist divides, individual constitutions state the parameters for the application of international instruments. As national legal orders become more and more influenced by globalisation, the relationship between national and international law becomes increasingly uncertain. While in some states, international law may be seen as complementing domestic law and therefore potentially enjoying a harmonious

\footnotetext{
${ }^{40}$ Decision No. 98-408 DC of 22 January 1999. See also, Chloé Charpy, 'The Status of (Secondary) Community Law in the French Internal Order: The Recent Case-Law of the Conseil Constitutionnel and the Conseil d'Etat' 3(2007) European Constitutional Review 436-462, 450.
} 
relationship, ${ }^{41}$ in others, it creates a tenuous co-existence. ${ }^{42}$ It is in this respect that conventionnalité may be seen as an appropriate tool to resolve tensions in the modern relationship between international and domestic law, by effectively treating international law as an integral part of the legal system.

Firstly, conventionnalité provides an alternative mechanism for judicial review of legislation, a fact which assumes additional significance in legal systems where the constitution does not allow for the review of legislation. In some states, when international law is incorporated into the legal system, it becomes subject to the constitution but is by no means inferior. Its importance is maintained by the fact that it is given primacy over other domestic legislation. In that sense, it becomes a point of reference for other domestic laws. Its 'constitutional' status is evident in the requirement for other legislation to be in conformity with it. Implicitly, the legislature is bound to ensure that any subsequent legislation conforms to the provisions of the international law. Further, the courts are implicitly empowered to review national law, for conformity with provisions of international treaties. This applies equally to domestic law which precedes the ratification and incorporation of any international law. It is still necessary for such domestic provisions to be in conformity with international laws applicable domestically. Domestic provisions which do not comply would be subject to review by means of conventionnalité. Peters argues that, in constitutional systems which do not provide for judicial review, the application of international human rights as a basis for review, fills a gap within that system. ${ }^{43}$ The mechanism of reviewing national law for conformity with international human rights law therefore amounts to a de facto constitutional review, which accords international human rights law a para-constitutional function. ${ }^{44}$

\footnotetext{
${ }^{41}$ Constitution of the Republic of South Africa 1996, Ss. 232-233. For a perspective on Kosovo see, " Visar Morina et al, 'The relationship between international law and national law in the case of Kosovo: A constitutional perspective' 9(1) (2011) International Journal of Constitutional Law 274-296.

${ }^{42}$ Anne Peter, 'Supremacy Lost: International Law Meets Domestic Constitutional Law' 3(2009) Vienna Journal of International Constitutional Law 170-171,183-194; Archibold Nyarango, 'A Jigsaw Puzzle or a Map? The role of Treaties under Kenya's Constitution' 62(1) (2018) Journal of African Law 25-50.

${ }^{43}$ Peters, 'Supremacy Lost'; 182-183.

${ }^{44}$ Peters, 'Supremacy Lost' 182-183.
} 
Secondly, conventionnalité can be seen as enabling international human rights to perform a para-constitutional function through the practical recognition of its primacy over national legislation. As in the case of France discussed above, international treaties, once duly ratified take precedence over other domestic legislation. It is the practical application of that supra-positive position by the domestic courts, through conventionnalité, that gives effect to the primacy of international law. That is akin to a typical review process by which the courts apply the domestic constitution as a point of reference, thereby giving practical recognition to the supremacy of the constitution.

Thirdly, through conventionnalité, international human rights law operates to reinforce a certain hierarchy within the domestic human rights system, akin to the role of domestic constitutions in hierarchisation of the legal system. The proposition proceeds on the assumption that all laws (domestic and international) derive their validity from a basic norm - the constitution. Domestic laws which may consist of acts of parliament, executive ordinances and regulatory instruments derive their validity from the constitution. Similarly, international law becomes applicable domestically because it has undergone the requisite constitutional procedures to be recognised domestically. Thus, both domestic and international law are recognised and applied by virtue of the constitution. If international law then supersedes domestic law (other than the constitution), it helps to maintain a hierarchy of laws within the system. In other words, the constitution remains at the apex, while international law is subordinate to the constitution and all other laws are subordinate to international law. The hierarchical approach suggests a certain consistency within the legal system, given that all norms ultimately derive their validity from the same basic norm -the constitution. There is no suggestion here that there could be no incompatible domestic law nor that international law could not conflict with the constitution. Where domestic legislation is incompatible with international law, the primary purpose of conventionnalite is to ensure that such a provision becomes inapplicable, therefore helping to maintain a harmonious human rights system. With respect to conflicts between international law and the constitution, the assumption is that such conflicts would be dealt with prior to ratification. For instance, in some monist systems such as France, where the provisions of a treaty appear to be 
inconsistent with the constitution, authorization to ratify that treaty is withheld until the amendment of the constitution. ${ }^{45}$ Where such inconsistencies become apparent only after ratification of the treaty, domestic courts have adopted varied approaches. ${ }^{46}$ Despite the possibility of inherent inconsistencies between international law and the constitution, conventionnalité retains importance where such inconsistencies are not an issue and the domestic system is devoid of a mechanism for review.

Admittedly, the effect of conventionnalité is not to invalidate the domestic provision as a mainstream review process would require. Its role is to ensure that the impugned provision is not applied to the particular case being dealt with. A litigant whose human rights were at stake would be able to avoid the application of a law restricting their rights. A decision following review by conventionnalité can also provide precedents which would be instructive to various levels of the judiciary when contemplating the application of similar provisions of domestic law or the same provision. This process is thus potentially less controversial in the sense that, it does not apply post-legislative judicial review, a process which may not be provided for by the constitution. Nevertheless, conventionnalité has the quality of acting as a review process, according international law a more forceful position within the domestic legal architecture.

\section{Conventionnalité and the Enforcement of International Human Rights in Francophone Africa}

One of the major features of the post-1990 constitutionalism revival in Africa is the express recognition of human rights in the constitutions and in some cases the express incorporation of international human rights treaties into domestic law. Nevertheless, the potential significance of international human rights is yet to be fully realised and exploited. In particular, with the exception of countries like South Africa, reference to international human rights by the courts has not often been consistent and persuasive. This results partly from the absence of a more unified system incorporating international

\footnotetext{
${ }^{45}$ Constitution of the Fifth French Republic, article 54.

${ }^{46}$ See for instance Akiangom Fombin Sebastien v Foto Joseph and others (Suit no. HCK/3/96 of 6 January 2000 (unreported), where a court in Cameroon refused to apply a regional treaty which was incompatible with the Constitution.
} 
law into domestic law, in a way that rather than emphasising the distinction between the two systems, they could be seen as an integral part of a system.

In francophone Africa in particular, the constitution provides that opportunity for international human rights to be more fully harnessed into the domestic human rights protection mechanism. The majority of former French colonies have constitutional provisions incorporating international human rights law into the domestic legal order, once the former has been duly ratified in accordance with the applicable legal procedures. In addition, some provisions tend to accord a higher status to international law over acts of parliament and other regulatory instruments. Like the French system, this creates an internal hierarchy through which the compatibility of domestic legislation, with international law, could be verified. In some countries, the practice of conventionnalité assumes particular importance because the constitutional systems are modelled on the traditional $^{47}$ French system which does not allow for post-legislative review. The effect is that, once a law has been enacted and promulgated, there is no scope for challenge on the basis of its constitutionality. In addition to that weakness, often, there is no individual access to the constitutional courts which are vested with jurisdiction in matters of constitutionality. Only a selected few, in many cases members of parliament and a very restricted category of the executive, can bring an action to challenge the constitutionality of a law before the constitutional court.

In a number of countries like Senegal, Côte D'Ivoire and Gabon, ${ }^{48}$ these weaknesses have been overcome in human rights litigation by what is known as 'l'exception d'inconstitutionnalité" (EI). This allows individuals during ordinary litigation to raise the issue of constitutionality of a domestic law where the law is alleged to infringe their human rights. In which case, consideration of the substantive matter is suspended, while the issue of constitutionality is referred to the constitutional court. This of course is commendable and helps to reinforce the importance of human rights. However, this

\footnotetext{
${ }^{47}$ The use of 'traditional' is to highlight the fact that, although the French system developed that way, since 2010, post legislative review is practiced in France through a system known as 'question prioritaire de constitutionnalité'.

${ }^{48}$ Law No. 2016-23 of 14 July 2016 on the Constitutional Council of Senegal, art 1; Constitution of the Republic of Côte D'Ivoire 2016, art. 135 and Constitution of Gabon 1991(as amended in 1997) art. 86.
} 
system is limited by the fact that the review is based obviously on the provisions of the constitution. Thus, a domestic law may potentially infringe human rights as more widely understood, but passes the constitutionality test because the law does not infringe any specific constitutional provision. This is the situation with LGBT rights which are not recognised by a significant number of African countries ${ }^{49}$ and indeed domestic law criminalises acts of a sexual nature between persons of the same gender. ${ }^{50}$ The situation is even more dismal in other countries which have neither post legislative review nor EI. In such countries, individuals are left to rely on the often inadequate and limited methods of protection of their human rights and often need to incur additional expenditure to access international jurisdictions in order to assert those rights not protected domestically. $^{51}$

Whereas, the practice of conventionnalité can mitigate some of these difficulties. In particular because the point of reference for review is based on international law which is comparatively more advance and comprehensive and provides a wider range of rights within the domestic legal system. Therefore, even in the absence of a domestic provision for a right, the international human rights treaty fills the gap and a state is bound to abide by its international obligations with respect to that right. Moreover, in countries which do not have the option of EI, the problem of individual access to the constitutional court is resolved by the fact that conventionnalite is practised by the ordinary courts of law which are open to ordinary citizens.

The next two sub-sections focus on Cameroon and Senegal examining in more detail the prospects for the development of conventionnalite in their domestic legal systems.

\footnotetext{
${ }^{49}$ According to Amnesty international, there are about 44 countries. See Amnesty International, 'Mapping Ant-gay Laws in Africa' 22/07/2015. Available at <https://www.amnesty.org.uk/lgbti-lgbt-gay-humanrights-law-africa-uganda-kenya-nigeria-cameroon $>$ accessed 27/04/2018.

${ }^{50}$ For instance, Law No. 2016/007 of 12 July 2016 relating to the Cameroonian Penal Code, section 347-1; the Senegalese Penal Code, article 319.3 and the Nigeria Same Sex Marriage (Prohibition) Act 2013, s.5.

${ }^{51}$ The African Court of Human and Peoples' Rights (AfCHPR) has even ruled that the absence of judicial review domestically indicates the absence of an effective domestic remedy for a violation of human rights. See Konate v Burkina Faso, Application No. 004/2013 (AfCHPR 5 December 2014), para. 109-113.
} 
Cameroon represents the extreme case with neither post legislative review nor EI, while Senegal exemplifies countries with EI but no post-legislative review.

\subsection{Cameroon}

\subsubsection{Scope of Judicial Review}

In Cameroon, the institution vested with responsibility in judicial review matters is the Constitutional Council ${ }^{52}$ which is vested with jurisdiction to rule inter alia on the constitutionality of laws, treaties and international agreements. ${ }^{53}$ The form of review envisaged by the law is the abstract model based on the traditional French a priori system of judicial review. The Constitution provides that, 'Laws as well as treaties and international agreements may, prior to their enactment be referred to the Constitutional Council $^{54}$ for determination of their constitutionality. This implies that a challenge relates to bills that have been adopted by Parliament prior to their promulgation. ${ }^{55}$ It therefore indicates that, the scope of review precludes review of enacted legislation. In addition to that limitation, there is also a restriction on standing. Only the following have access to the Council; the Head of State, the presidents of the National Assembly and Senate and one-third of the members of the National Assembly or Senate. ${ }^{56}$ Heads of regional executives also have access to the Council where the interest of their regions is likely to be affected by legislation. ${ }^{57}$ From the perspective of the ordinary man, this amounts to a denial of access to justice in that an ordinary individual cannot challenge the constitutionality of a law infringing their human right. They have to depend on legislative and executive authorities who are responsible for the production and execution of such laws and would be most likely reluctant to challenge their own laws. It is against this background that an alternative to judicial review is imperative and conventionnalité can

\footnotetext{
${ }^{52}$ Constitution of Cameroon, art 46

${ }^{53}$ Constitution of Cameroon, art 47.

${ }_{55}^{54}$ Constitution of Cameroon, art 47(3); Constitutional Council Law, art 3 (1).

55 Charles Fombad, 'The New Constitutional Council in a Comparative Perspective: Progress or Retrogression?' (1998) 42(2) Journal of African Law 180, 171.

${ }^{56}$ Constitution of Cameroon, arts 47(2) (3); Constitutional Council Law, art 19(1).

${ }^{57}$ However, according to art 48(2) of the Constitution, an individual can invoke the jurisdiction of the Council to challenge the regularity of parliamentary elections where that individual was a candidate in the elections or acted as an agent of the government in the elections.
} 
be seen as providing the basis for international human rights to assume that paraconstitutional function of ensuring that domestic legislation in Cameroon is compatible with international human rights treaties ratified by Cameroon.

\subsubsection{Constitutional basis for Conventionnalité}

Treaties are recognised as part of the corpus of law in Cameroon. The Head of State is vested with the authority to ratify treaties and international agreements and in some instances, authorisation is required from parliament for such treaties or agreements to be ratified. ${ }^{58}$ Article 44 regulates the relationship between the Constitution and international treaties. It states that where the Constitutional Council finds the provisions of a treaty or an international agreement unconstitutional, ratification shall be deferred until the Constitution is amended. ${ }^{59}$

The basis for conventionnalité can be traced to article 45 of the Constitution which gives primacy to duly ratified international instruments. It provides that, 'Duly approved or ratified treaties and international agreements shall, following their publication, override national laws, provided the other party implements the said treaty or agreement' ${ }^{60}$ This provision implies a certain hierarchy within the domestic legal system by making all other domestic law subordinate to international law. ${ }^{61}$ Although the Constitution does not expressly provide for conventionnalité, a constitutionalist reading of the provision indicates that there is a requirement of conformity of domestic law with international law. Just like the Constitution which provides the basis for the legality of all other norms, once duly ratified through the applicable channels, international human rights law provides the basis for the legality of domestic legislation given that the latter now becomes

\footnotetext{
${ }^{58}$ Constitution of Cameroon, art 46.

${ }^{59}$ Constitution of Cameroon, art 44.

${ }^{60}$ With respect to the reciprocity agreement, it is now generally accepted in Francophone Africa that the requirement is not applicable to human rights instruments. See Sall A, 'Le Droit International dans les nouvelles constitutions Africains' 1(1997) R.J.P.I.C, 350. With respect to Cameroon, the human rights exception was confirmed in 'Report of the Ministry of Justice on Human Rights in Cameroon 2005' October 2006, p.22 (n) 10, available at www.minjustice,gov.com.

${ }^{61}$ Michel Zouhair Fadoul v Omaïs Kassim et Société Omaïs Selecta Sarl, Arrêt No. 21/Civ/CS/CJ of 15 July 2010, available at http://www.ohada.com/jurisprudence/ohadata/J-12-242.html.
} 
subordinate to it. ${ }^{62}$ The relationship that international law creates is a hierarchical one which also enhances consistency within the domestic legal order. This is seen in the fact that first it is in harmony with the Constitution based on the presumption that its ratification indicates that it is not incompatible with the constitution. It therefore becomes a part of domestic law thereby supplementing constitutional provisions on human rights. Secondly, if it operates to ensure domestic law is consistent with its provisions, then the entire legal system becomes one that embodies recognised principles of international human rights norms.

The Constitutional basis for Conventionnalite and the issue of hierarchisation was discussed by the Supreme Court of Cameroon in Fadoul v Omaïs Kassim ${ }^{63}$. The case concerned the enforcement in Cameroon, of a deed drawn up by a notary public in Benin. The Court of Appeal in the Littoral Region of Cameroon had erroneously submitted to a process of authentication and subsequently declared unenforceable. The basis of the Appeal Court's decision was section 10 of the Cameroonian Law on Foreign Judgments, ${ }^{64}$ which provided for additional procedures of authentication to be followed, prior to the execution of foreign judgements and other judicial orders or instruments, in particular notarised deeds. In the Supreme Court, the appellants argued that section 10 of that domestic law was incompatible with article 29 of the General Convention on Judicial Cooperation to which Benin and Cameroon were parties. Article 29 provides a list of documents that are directly enforceable in all member states to the Convention. That list includes, notarised deeds issued by the relevant authorities in the member states and certified by the same authority to establish authenticity. According to the appellants, given that the notarised deed fell within the scope of article 29, it should have been directly enforceable without being submitted to a process of authentication by the courts in Cameroon.

\footnotetext{
${ }^{62}$ Fadoul v Omaïs, at para 3.

${ }^{63}$ Note 61 above.

${ }^{64}$ Law No. 2007/001 of 19 April 2007 To Institute a Judge in Charge of Litigation Related to the Execution of Judgments and Lay Down Conditions for the Enforcement in Cameroon of Foreign Court Decisions, Public Acts and Arbitral Awards.
} 
In deciding on the issue, the Supreme Court referred to article 45 of the Constitution of Cameroon. The Supreme Court was emphatic that article 45 of the Constitution necessitates a system of hierarchy by which subordinate legislation (domestic law) could not be inconsistent with superior legislation (international law). ${ }^{65}$ In that respect, article 45 confers on the courts powers to exercise 'le contrôle de la conventionnalité' to make the treaty obligation prevail over national law where there is an inconsistency with a domestic provision as in the present case. ${ }^{66}$ The effect is that, the domestic law is excluded from application to the dispute in question. ${ }^{67}$ Accordingly, article 29 of the Convention prevails, implying that the document issued by the Beninese notary public should not have been submitted to additional authentication procedures by the Littoral Court of Appeal. In annulling the decision of the lower court, the Supreme Court went further to state that, the rationale for article 29 of the Convention was to eliminate the disparities likely to arise in the different laws of the member states, which may undermine the purpose of the Convention to strengthen relationships in matters of judicial cooperation. $^{68}$

Fadoul thus presented an opportunity for the Supreme Court to firmly establish the constitutional basis for the practice of conventionnalité in Cameroon. Given that Fadoul is a decision of the supreme appellate jurisdiction in Cameroon, it should set precedence for lower courts to adopt. However, as discussed below, it is doubtful to what extent the practice of conventionnalité can be fully developed as a de facto judicial review mechanism to protect human rights in Cameroon.

\subsubsection{Judicial Attitudes to International Law and Conventionnalité}

The courts in Cameroon have often referred to international law when deciding cases, although it is not a common practice for it to form the basis of a decision. ${ }^{69}$ For instance

\footnotetext{
${ }^{65}$ Fadoul v Omaïs, at para 3.

${ }^{66}$ Fadoul v Omaïs, at para 4.

${ }^{67}$ Fadoul v Omaïs, at para 4.

${ }^{68}$ Fadoul v Omaïs, at para 3.

${ }^{69}$ Brusil Metou 'Le Moyen de Droit International Devant Les Juridictions Internes en Afrique : Quelques Exemples d'Afrique Noire Francophone' (2009) 22(1) Revue Québécoise de Droit International 129, 135; A.D. Olinga, 'Réflexions sur le droit international, la hiérarchie des normes et l'office du juge camerounais', 63(2005) Juridis Periodique, 9.
} 
in The People $v$ Nya Henry the Court affirmed that the presumption of innocence was recognised by the Constitution of Cameroon and also protected under article 11 of the Universal Declaration of Human Rights, to which Cameroon affirms its attachment. However, in arriving at a decision that there had been a breach of that right, the Court did not base its decision on the international instrument. In that particular case, perhaps it was unnecessary as the right was protected under domestic law. Would the situation be different if a right were not provided for under Cameroonian law?

To address that question, it may be helpful to refer to a particularly controversial issue within domestic law - the rights of sexual minorities. The Cameroonian Penal Code ${ }^{70}$ criminalises acts of a sexual nature between persons of the same gender with punishments attracting a custodial sentence of up to five years and a fine of up 200,000 FCFA $^{71}$. Partly ${ }^{72}$ as a result of that law, there is intolerance of homosexuality and Cameroonians suspected of homosexuality have been victims of arbitrary arrests and detention, torture and degrading treatment while in custody. ${ }^{73}$ In addition, the law is incompatible with Cameroon's international obligations such as articles 2, 9 and 17 of the International Covenant on Civil and Political Rights (ICCPR) which respectively protect the rights to equality, personal liberty and privacy. Ironically, article 2(1) of the Penal Code states that the Code is subject to rules of international treaties ratified by Cameroon. This is an indication that the legislator intended that the Code should be compatible with provisions of international laws that are applicable in Cameroon. That provision, read together with article 45 of the Constitution (which gives primacy to international law) should provide a sound basis for resorting to conventionnalité for a declaration that the domestic law is incompatible. As was stated clearly in Fadoul, an incompatible domestic provision must 'give way to international law'. ${ }^{74}$ Cameroonians seeking to challenge

\footnotetext{
${ }^{70}$ Law No. 2016/007 of 12 July 2016 relating to the Penal Code, section 347-1.

${ }^{71}$ Approximately $£ 280$.

${ }^{72}$ Intolerance also emanates from cultural and religious doctrines on homosexuality.

${ }^{73}$ Human Dignity Trust, 'Criminalisation of Homosexuality: Cameroon' October 2015. Available at http://www.humandignitytrust.org/uploaded/Map/Country_Reports/Cameroon.pdf (last accessed 28 December 2017); Human Rights Watch, 'Guilty by Association: Human Rights Violations in the Enforcement of Cameroon's AntiHomosexuality Law'. Available at http://www.hrw.org/sites/default/files/reports/cameroon313_Upload.pdf (last accessed 28 December 2017). ${ }^{74}$ Fadoul, para 4.
} 
charges or convictions based on section 347-1 of the Penal Code can resort to article 45 of the Constitution and the authority of Fadoul to challenge the compatibility of that provision with articles 2, 9 and 17 of the ICCPR.

Despite the sound constitutional basis for conventionnalité, the approach of the courts has not been consistent and therefore, it is not clear what approach they may adopt to a challenge of the compatibility of domestic law. The Courts have been more forthright where the domestic law is compatible with international law. For instance in Mä̈ramou Oumarou $^{75}$ which concerned an attempted forced marriage, the Court of First Instance in Ngaoundéré (although not called upon to rule on compatibility) confirmed that section 356 of the Penal Code which prohibits forced marriage was compatible with the Convention on the Elimination of All Forms of Discrimination against Women (CEDAW) ${ }^{76}$ In S.A. Ami Voyage v Ayisi Ndzana et autres ${ }^{77}$ the Court of First Instance in Yaoundé in reference to a community $\operatorname{law}^{78}$ stated that the court is obliged by the provisions of that law to give preference to it over any incompatible domestic provision. ${ }^{79}$ It stated further that, the primacy of international law has been given effect by article 45 of the Constitution and therefore endorses the overriding effect of the OHADA Treaty over national law.

It has been argued that, the courts were more forthright in the above cases because the issues were uncontroversial in that the relevant domestic laws were compatible with international law. ${ }^{80}$ Thus, the courts would be more reluctant when faced with

\footnotetext{
${ }^{75}$ Maïramou Oumarou, Jugment No. 404/cor of 12 May 2003, discussed in Metou, 'Le Moyen de Droits International' 161-162.

${ }^{76}$ See Conventions on the Elimination of All Forms of Discrimination Against Women, art 16(1) 'States Parties shall take all appropriate measures to eliminate discrimination against women in all matters relating to marriage and family relations and in particular shall ensure, on a basis of equality of men and women'; (b) 'The same right freely to choose a spouse and to enter into marriage only with their free and full consent.'

${ }^{77}$ S.A. Ami Voyage v Ayisi Ndzana et autres, Ordonnance de Référé No. 200/C/TPI/Y of 30 November 2000 (unreported).

${ }_{78}^{78}$ Treaty on the Harmonisation of Business Law in Africa (OHADA), 17 October 1993

${ }^{79}$ Article 10 of the OHADA Treaty states that, 'Uniform Acts are directly applicable and overriding in the Contracting States notwithstanding any conflict they may give rise to in respect of previous or subsequent enactment of municipal laws'.

${ }^{80}$ Metou, 'Le Moyen de Droits International' 161-162.
} 
controversial issues. ${ }^{81}$ That assertion may find some support from the approach of the courts in other cases. In Wakai \& 172 Others $v$ The People ${ }^{82}$ which concerned serious violations of human rights by security and administrative officials, the High Court in Mezam was keen to emphasise that it was not engaging in judicial review of legislation for which it has no jurisdiction. The Court stated that it was concerned with the legality of the acts carried out by the state officials, rather than the regulatory instruments under which the acts had been effected. The Court stated that,

'It is settled law that when there is any action purportedly under local legislation which conflicts with international conventions to which the country in question is a signatory, the action under local legislation must give way to the international convention..., 83

It is possible to attribute the reluctance of the Courts to address the issue of compatibility of the law due to possible controversies. For instance, some of the regulatory instruments which authenticated human rights abuses in that case were based on provisions of the law on the maintenance of public order $^{84}$ which may be considered incompatible with international treaties such as the ICCPR. ${ }^{85} \mathrm{~A}$ similar reluctance was demonstrated by the court in Ministère Public v Mounchipou ${ }^{86}$ where the defendants had been charged with embezzlement and attempted embezzlement of public funds. They repeatedly raised the issue of compatibility of the domestic law under which they were charged, with provisions of the Marrakesh Agreement Establishing the World Trade Organisation. ${ }^{87}$ Nevertheless, in deciding against the applicant the Court refrained from addressing the issue of compatibility. More significantly, in Njoya Thomas v État du Cameroun ${ }^{88}$, the Supreme Court resorted to conventionnalité to determine the compatibility of an administrative act (rather than domestic law) with international law. In that case, $\mathrm{Mr}$

\footnotetext{
${ }^{81}$ ibid.

${ }^{82}$ Wakai \& 172 Others $v$ The People (1997) 1CCLR 127.

${ }^{83}$ Wakai v The People at 136. Author's emphasis.

${ }^{84}$ Law No. $90 / 54$ of 19 December 1990 on the Maintenance of Law and Order.

${ }^{85}$ Section 2 of the law on the Maintenance of Public Order vests administrative authorities with powers to arrest and detain people for a renewable period of 15 days (renewable indefinitely) to fight banditry. That is not compatible with pre-trial detention requirements under article 9(3) of the ICCPR.

${ }^{86}$ Ministère Public et Ministère des Postes et Télécommunications v Sieur Mounchipou et Autres, discussed in Metou 140.

${ }_{87}$ The Marrakesh Agreement Establishing the World Trade Organisation, April 1994. Available at $<$ www.wto.org/english/docs_e/legal_e/04-wto.pdf>.

${ }^{88}$ Njoya Thomas v The State of Cameroun Arrêt No. 7 CS/CA of 26 October 1978.
} 
Njoya challenged the conformity of an administrative decision ${ }^{89}$ affecting an intellectual property right conferred under a community law. ${ }^{90}$ Although the administrative authority acted pursuant to domestic law, the Court was careful not to question the domestic law. It nevertheless annulled the administrative act on the basis that it was incompatible with provisions of the community law. It is not clear why the Court failed to address the domestic law. The reason may be because the parties appeared to be more concerned with the administrative act rather than domestic law and the Court could arrive at the same result without dealing with the difficult issue of reviewing legislation.

It should be noted however that the above decisions preceded Fadoul which is a more authoritative decision on issues of conventionnalité. In fact, the Supreme Court in Fadoul appears to have sparked debates on the issue of the primacy of international law and possibly laid to rest the question as to whether the courts in Cameroon have the authority to exercise de facto judicial review through conventionnalité ${ }^{91}$

\subsection{Senegal}

\subsubsection{Scope of Judicial Review}

In Senegal, the institution vested with jurisdiction in judicial review matters is the Constitutional Council. ${ }^{92}$ The method of review envisaged includes both a prior judicial review and post legislative judicial review (although within narrow limits). Under the first method, laws and international agreements may be referred to the Constitutional Council for determination of their constitutionality prior to their promulgation. ${ }^{93}$ This implies that preventive control of the constitutionality of a law is exercised prior to its enactment. Standing is limited to the President of the Republic and one-tenth of the

\footnotetext{
89 Decision No. 2411-MINFOC-DAC of 28 July 1975 of the Minister of Information and Culture, prohibiting Mr Njoya from exercising his patent rights.

90 l'Office Africain et Malgache de la Propriété Industrielle (OAMPI) 1963 (now known as l'Organisation Africaine de la Propriété Intellectuelle (OAPI) 1977 (The African Intellectual Property Organisation).

${ }^{91}$ Therese Atangana-Malongue, 'Le Juge Camerounais et le Droit International' in J. L. Atangana (ed) Le Cameroun et le Droit International (Éditions A. Pedone 2014) 301, 303.

${ }^{92}$ Constitution of Senegal, art 92 (as amended by Constitutional Law No. 2016-10 of 05 April 2016) and Law No. 2016-23 of 14 July 2016 on the Constitutional Council (Constitutional Council Law), art 1.

${ }^{93}$ Constitution of Senegal, art 92, Constitutional Council Law, art1.
} 
members of the National Assembly. ${ }^{94}$ Thus, ordinary citizens are precluded from accessing the Constitutional Council to exercise preventive control.

The second method of control is by way of 'l'exception d'inconstitutionnalité'. This is a method by which the jurisdiction of the Constitutional Council can be invoked to review a legislative provision already in force to determine its compatibility with the constitution. ${ }^{95}$ The law provides that, in the course of proceedings before a Court of Appeal or the Supreme Court, a litigant may raise the issue of the constitutionality of a law or an international instrument that may affect their rights if applied in the particular case. The court is obliged to refer the matter to the Constitutional Council for a decision on the constitutionality of the law. ${ }^{96}$ The proceedings in the lower court are suspended whilst the Constitutional Council considers the matter. ${ }^{97}$ Where a law is declared unconstitutional, it cannot be applied. ${ }^{98}$

From the above, it can be argued that the Senegalese system provides avenues for judicial review which are not available to other countries like Cameroon. There is an opportunity for preventive control of legislation, albeit limited by the fact that only the President and members of parliament have standing. Again, l'exception d'inconstitutionnalité' provides a good avenue for the ordinary citizen to challenge the application of a law which is unconstitutional. This indicates that, a law which potentially infringes a fundamental human right can be challenged to prevent its application even after it has been enacted and is in force. ${ }^{99}$ Nevertheless, there is a weakness in this system which may not be so obvious - the fact that the challenge is based on constitutional provisions. As such, where a law potentially infringes human rights which are not protected by the constitution or are limited by the constitution, it may still be applied if it is not inconsistent with the

\footnotetext{
${ }^{94}$ Constitution of Senegal, art 74. See also Constitutional Council Law, art1.

${ }^{95}$ Constitutional Council Law, art1.

${ }^{96}$ Constitutional Council Law, art. 22.

${ }^{97}$ ibid.

${ }^{98}$ ibid.

${ }^{99}$ See for instance Conseil Constitutionnel, Decision No. 11-93, 23 June 1993 (ACCPUC Bulletin No. 1, September 1998) where a domestic law was declared unconstitutional due to its inconsistency with the constitutional right to equality guaranteed under article $1 \& 7$ of the Constitution.
} 
constitution. For instance, the Constitutional Council has held a domestic law ${ }^{100}$ restricting the right to join a trade union and the right to strike not to be unconstitutional $^{101}$ on the basis that the constitutional right is not absolute. ${ }^{102}$ The approach of the Constitutional Council, makes resort to international human rights law and the practice of review by way of conventionnalité necessary. The advantage of such a system is the obvious fact that the point of reference here is international law which presumably provides a wider range of rights than is available domestically. It may be asked at this point whether there is a constitutional basis for conventionnalité?

\subsubsection{Constitutional Basis for conventionnalité}

In Senegal, the President of the Republic is vested with the authority to negotiate international agreements and to ratify or approve them on the authorisation of parliament. ${ }^{103}$ International agreements may be referred to the Constitutional Council for a decision on their constitutionality. ${ }^{104}$ Where the Constitutional Council has declared that an international agreement contains a clause that is contrary to the Constitution, the authorisation to ratify it shall only be given after a revision of the Constitution ${ }^{105}$

The constitutional basis for conventionnalite is article 98 of the Constitution. It provides that, duly ratified international treaties shall, upon their publication, have an authority superior to that of laws, subject for each treaty or agreement, to its application by the other party. ${ }^{106}$ The provision allows for the direct application of international instruments once ratified through the applicable legal channels and once the requirement of publication has been satisfied. ${ }^{107}$ An international instrument that has gone through the

${ }^{100}$ Law No. 69-34 of 30 ${ }^{\text {th }}$ October 1969 on the Status of Customs Staff, art. 8.

${ }^{101}$ Conseil Constitutionnel, Affaire No. 2/C/2013, 17 July 2013.

${ }^{102}$ Constitution of Senegal, art. 25.

${ }^{103}$ Constitution of Senegal, art. 95.

${ }^{104}$ Constitution of Senegal, art. 97; Constitutional Council Law, art. 1.

${ }^{105}$ Constitution of Senegal, art. 92; Constitutional Council Law, art. 18.

${ }^{106}$ See above (n.) for the non-applicability of the reciprocity requirement in human rights treaties.

${ }^{107}$ Fatou Marone, 'La Convention Contre la Torture et son Application au Niveau National: Le Cas du Sénégal dans l'Affaire Hissène Habré' in Magnus Killander (ed) International Law and Domestic Human Rights Litigation in Africa (PULP 2010) 193-204, 193-194; D. N'doye, La Constitution Sénégalaise du 7 Janvier 2001 Commentée et Ses Pactes Internationaux Annexés: Les Perspectives Politiques, Juridiques et Sociales (Editions Juridiques Africaines 2001) 39. See also AfriMAP: Open Society Initiative for West Africa, 'Le Sénegal: Le Secteur de la Justice et de l'Etat de droit' (Open Society Initiative 2008) 21. 


\subsubsection{Judicial Attitudes to International Law and Conventionnalité}

There is judicial uncertainty with respect to the status of international law as a direct source of law in Senegal, an uncertainty which has led to its weak and often reluctant application by the courts. ${ }^{111}$ The courts have referred to international law in a few cases

\footnotetext{
108 ibid.

${ }^{109}$ Marone, 'La Convention Contre la Torture et son Application au Niveau National' 194.

${ }^{110}$ Human Rights Watch, 'Senegal: Law Promotes Violence against Homosexuals' 30 November 2010. Available at <.https://www.hrw.org/news/2010/11/30/senegal-law-promotes-violence-against-homosexuals $>$ last accessed 12 January 2018.

${ }^{111}$ AfriMAP: Open Society Initiative for West Africa, 'Le Sénegal: Le Secteur de la Justice’ 21.
} 
and rarely in a way which determines the outcome of the case. ${ }^{112}$ There seems to be a reluctance to apply international law in a way that forms the basis of a decision. For instance, in Prospère Guéna Nitcheu et autres v Université Cheikh Anta Diop de Dakar, ${ }^{113}$ the court acknowledged that the right to equal access to education provided for under article 26 of the Universal Declaration of Human Rights (incorporated into the Constitution of Senegal) imposed a duty on administrative authorities to respect that right. However, in arriving at a decision that the right had not been breached in that case, the court did not refer to the Universal Declaration or other instruments mentioned by the complainants.

A similar approach was adopted in L'Association des Handicapée Moteur du Sénégal v État du Sénégal. ${ }^{114}$ In that case, an action was brought by an association for persons with disability on behalf of Boubacar Fadiya who had been excluded from a government teachers' training recruitment programme on the basis of his disability. The complainants argued that the administrative decision excluding Boubacar violated the right to equal access to employment in the public service guaranteed by a number of international instruments ratified by Senegal ${ }^{115}$. The Court annulled the impugned administrative decision on the basis that it violated the stated right. However, its decision was not based on any of the instruments referred to by the complainants. Although the Court acknowledged the instruments, it did not find it necessary to address the issue of their violation or the constitutional principle of the hierarchy of norms. ${ }^{116}$ It may be argued that in the above cases, the courts did not find it necessary to refer to international law as the rights violated were protected by the Constitution.

\footnotetext{
${ }_{112}^{112}$ Marone, 'La Convention Contre la Torture et son Application au Niveau National' 193.

${ }^{113}$ Prospère Guéna Nitcheu et autres v Université Cheikh Anta Diop de Dakar, Arrêt No. 1, Bulletin des Arrêt du Conseil d'État No. 1, p. 83. Discussed in Marone, 'La Convention Contre la Torture' 195-196.

${ }^{114}$ L'Association des Handicapée Moteur du Sénégal v État du Sénégal, Arrêt No.12, 29 June 2000. Bulletin des Arrêt du Conseil d'État No. 2, 1998-2000 (2002) 28-30.

115 They referred inter alia to the International Labour Organisation, Discrimination (Employment and Occupation) Convention, 1958 (No. 111), art. 1 and the African Charter on Human and Peoples' Rights, arts. 31 and $18(4)$.

${ }^{116}$ For an extensive discussion of the case, see Moustapha Ngaide, 'Le Conseil d'Etat du Senegal et le Principe de l'Egal Access des Citoyens a un Emploi Public: A Propos de l'Arrêt du 29 Juin 2000: L'Association des Handicapée Moteur du Sénégal v État du Sénégal (Arrêt No. 12) 03(2003) Revue Electronique Afrilex, 193-222, 204.
} 
Nevertheless, it has been noted that, generally, the courts are strongly opposed to the direct application of international treaties and, as a result, completely undermine the principle provided for under Article 98 of the Constitution. ${ }^{117}$ In some instances where the courts have acknowledged the supremacy of international law, they have failed to give effect to it. That approach was demonstrated in the infamous Hissène Habré ${ }^{118}$ case which concerned the prosecution in Senegal, of the former Chadian dictator, Hissène Habré, for torture, cruel, inhuman and degrading treatment committed on victims in Chad during his presidency. ${ }^{119}$ One of the issues in that case was that although the alleged crimes were punishable under domestic law, they were not amongst the crimes listed in article 669 of the Senegalese Criminal Procedure Code (CPC), for which a foreigner could be prosecuted for crimes committed abroad. The other issue was the prosecution of Habré, for crimes against article 1 of the Convention Against Torture. ${ }^{120}$ The Court of Appeal in Dakar held that Senegalese national courts did not have jurisdiction to prosecute Habré. The Court noted that, the Convention was not self-executing and as per its article 5(2), required Senegal to enact domestic provisions to vest the courts with universal jurisdiction. That decision was upheld on further appeal ${ }^{121}$ to the Court of Cassation. ${ }^{122}$ It stated that, article $98^{123}$ of the Constitution could not be applied where the Convention makes it necessary for Senegal to take prior legislative measures and which it had failed to do. ${ }^{124}$ The Courts failed to consider articles 27 and 53 of the Vienna Convention (applicable in Senegal) that prohibit a signatory to an international

${ }^{117}$ AfriMAP, 'Le Sénegal: Le Secteur de la Justice' 21.

118 Ministère Public et François Diouf v Hissène Habré, Cour d'Appel, Arrêt No. 135 of 4 July 2000. Available at http://www.hrw.org/french/themes/Habré-decision.htm. Last accessed 12 January 2018.

${ }^{119}$ An indepth discussion of that case can be found in M. Niang, 'The Senegalese Legal Framework for the Prosecution of International Crimes' 7(2009) 1047-1062; Valentina Spiga, 'Non-retroactivity of Criminal Law: A New Chapter in the Hissène Habré Saga' 9(2011) 5-23.

${ }^{120}$ Convention Against Torture and Other Cruel, Inhuman, Degrading Treatment or Punishment 1984.

${ }^{121}$ Souleymane Guengueng et Autres v Hissène Habré (2002) AHRLR 183 (SeCC 2001.

${ }^{122}$ In 1992, the Supreme Court of Senegal was dissolved and its jurisdiction shared between Constitutional Council, the Council of State (highest appellate administrative jurisdiction) and the Court of Cassation (highest appellate ordinary jurisdiction). However, the Supreme Court was reinstated in 2008 by Law No. 2008-35 of 7 August 2008 on the Supreme Court. The functions of the Court of Cassation and the Council of State are sperformed by the Supreme Court.

${ }^{123}$ It should be noted that the provision referred to in the case was article 79 of the Constitution. That provision is now article 98 following a constitutional referendum in 2001 during which the current constitution was approved.

${ }^{124}$ Souleymane Guengueng, para 39. 
convention from relying on the gaps and insufficiencies of its domestic law to extricate itself from its international commitments. Both Courts acknowledged the supremacy provision in the constitution, by virtue of which article 669 of the CPC became subordinate to the Convention once it was ratified and published domestically. Nevertheless, they preferred to apply domestic law to prevent the prosecution of Habré. Although there might have been a political angle to the Habré saga, the case demonstrates how far the courts would go to avoid giving effect to article 98 of the Constitution.

In another decision, the court clearly expressed its intransigence towards the supremacy of international law. In Séga Seck Fall, ${ }^{125}$ following the sentencing of the complainant, (the leader of a trade union) to six months imprisonment, the said union was dissolved by presidential decree. The basis of the decree was a domestic law which authorised the dissolution by decree, of associations or groups whose activities threatened the operation of the constitutional regime. ${ }^{126}$ The complainant challenged the validity of the presidential decree on the basis that it was incompatible with article 4 of the World Trade Organisation Convention No. 87, forbidding the dissolution of an employee association by an administrative act. The Supreme Court rejected the claim on the basis that the Convention was not applicable in Senegal. It held that, there was no proof of publication of the Convention, contrary to the requirements of article 98. It went further to state that, assuming the Convention was applicable, it could not in 'the present conditions' prevail on the law which the impugned decree legally takes from. It is not clear why the court took that approach despite the constitutional supremacy of international treaties. In particular, the court did not specifically elaborate on 'the present conditions' which made the supremacy principle inapplicable in that case. The court's attitude demonstrates judicial unwillingness to give primacy to international law, an attitude which ultimately undermines the constitutional hierarchy ${ }^{127}$ under article 98 that ironically the court referred to.

125 Séga Seck Fall, Cour Supreme, 29 January 1975, Les Grandes Décisions de la Jurisprudence Administratif Sénégalaise ( ${ }^{\text {rd }}$ ed. Dakar: R.I.P.A.S 1987) 114.

${ }^{126}$ Law No. 65-40 of 22 May 1965 on Seditious Associations, art. 1.

${ }^{127}$ Marone, 'La Convention Contre la Torture' 195. 


\section{Prospects for the Development and Entrenchment of Conventionnalité in Cameroon and Senegal}

The preceding section has demonstrated that in both Cameroon and Senegal, there is sound constitutional basis for international law to perform a para-constitutional function through the practice of conventionnalité. The question however, is the willingness of the courts to developed and entrench that practice. The courts in the two countries appear in practice, to have a divergent approach. While the courts in Cameroon appear to be slow in applying international law, it may be argued that Fadoul demonstrates that they may be amenable to giving greater effect to it. Whereas, the courts in Senegal seem apathetic if not inimical to the idea of giving primacy to international law.

An important factor which may account for the reluctance of the courts in both countries may be the absence of an express provision for conventionnalite in the constitutions of Senegal and Cameroon respectively. The courts may be more inclined to responding to clear constitutional provisions, rather than adopting a creative interpretation of constitutional provisions. Nevertheless, it is recognised that the courts occupy a very central position in the protection of fundamental rights and are in a good position to give effect to international law. ${ }^{128}$ It has been argued that, due to the proximity of domestic courts to litigants, as opposed to international jurisdictions, the national courts are in the best position to protect rights guaranteed by international instruments. ${ }^{129}$ Moreover, with increasing regional integration (in Africa), there is more interaction between regional and domestic law, making the need for a more harmonious co-existence of national and international (regional) law. ${ }^{130}$ Conventionnalité is therefore becoming more imperative. ${ }^{131}$ Thus, despite the absence of an express provision in the constitutions, the

\footnotetext{
${ }^{128}$ Atangana-Malongue, 'Le Juge Camerounais et le Droit International' 301.

${ }^{129}$ Atangana-Malongue, 'Le Juge Camerounais et le Droit International 304.

130 Edouard Tonnang and Arsène Nguena Djoufack, 'L'Influence du droit communautaire de la communauté Economique et Monétaire de l'Afrique Centrale (CEMAC) sur le Domaine de la Competence du Juge Administratif Camerounais' (2012) RETCH in Afrika 83-11, 93; Hartmut Hamann, 'The Future Implementation of the Rule of Law: Preconditions, Challenges and Perspectives' in Arne Wulff \& Peter Wendoh (eds) Supporting the Rule of Law in Africa: 10 Years of the Rule of Law Programme in SubSaharan Africa 2006-2016 (Konrad Adenauer Stiftung 2017) 101-106.

${ }^{131}$ Tonnang \& Djoufack, 'L'Influence du droit communautaire , 93.
} 
courts could be creative in following the approach of the French courts, to develop and entrench that practice domestically. ${ }^{132}$

In both countries, the absence of an express provision may additionally have a correlative effect on judicial knowledge of that practice. If the courts are largely unaware of such a practice, then it is not unreasonable that it has not taken effect. In Senegal for instance, the Open Society Initiative for Africa has commented that the courts are uncertain as to the status of international law in Senegal, partly accounting for their attitude towards its application. ${ }^{133}$ In addition, perhaps the reticence of the Senegalese courts and the lower courts in Cameroon can be attributed to the desire to preserve the harmony of domestic law and therefore, giving more effect to international law might create difficult problems of interpretation which the courts may be ill-equipped to deal with. One may therefore argue that, judicial training on the position of international law and in particular, the role of conventionnalité might be a way forward in enhancing the prospects for the development and entrenchment of that practice. ${ }^{134}$

Moreover, even with some awareness of the practice, the absence of an express constitutional provision may deter judges from asserting their authority to give precedence to international law. It has been argued that, legal systems tend to reflect the cultures within which they are situated and it is well noted that judiciaries in francophone Africa tend to lack sufficient judicial independence. ${ }^{135}$ This is true of Senegal ${ }^{136}$ and of Cameroon ${ }^{137}$ and is a culture that is entrenched in systems based on the French civilian constitutional model. That position of lack of judicial independence may inherently

\footnotetext{
${ }^{132}$ Tonnang and Djoufack, 'L'Influence du droit communautaire' 93.

${ }^{133}$ AfriMAP: Open Society Initiative for West Africa, 'Le Sénegal: Le Secteur de la Justice

${ }^{134}$ That position is endorsed by the Open Society. See AfriMAP: Open Society Initiative for West Africa' 7. See also 'The Future Implementation of the Rule of Law' 100-106.

${ }_{135}$ Charles Fombad, 'A Preliminary Assessment of the Prospects for Judicial Independence in Post-1990 African Constitutions' (2007) Public Law 233, 243-244, 249-251; André Cabanis and Michel L.Martin, Les Constitutions d'Afrique Francophone: Evolution Récentes, (KARTHALA 1999) 153-160.

${ }^{136}$ Demba Sy, 'La Condition du Juge en Afrique: L'Example du Sénégale' 3(2003) Afrilex: Revue d'Etude et de Recherche sur le Droit et L'Administration dans les Pays d'Afrique' 1-9.

${ }^{137}$ Laura-Stella Enonchong, 'Judicial Independence and Accountability in Cameroon: Balancing a Tenuous Coexistence' 5(3) (2012) African Journal of Legal Studies 313-337; Muambo Evande J, 'Empowering the Judiciary: Making Judicial Power Possible' 1 (2001) The Imperial Judge: SOWEMAC Judicial Journal 42, 47-48.
} 
inhibit the disposition of judges towards introducing a practice that has the potential to review laws that were initiated by the executive. In the cases discussed on Cameroon and Senegal which pitted individual rights against executive actions, the judges were not forthright in condemning the legislative provisions which were basis for the executive acts. In the Hissèn Habré case for instance, it is no secret that Habré was under the protection of the President of Senegal who had shown no inclination to allow Habré to be subject to any international jurisdiction. It would have required an uncharacteristically audacious judge to go against the President's wishes. But the Supreme Court in Cameroon has demonstrated in Fadoul that the courts can become assertive, particularly because there is constitutional basis for developing and entrenching the practice of conventionnalité.

\section{Conclusion}

International human rights have undoubtedly acquired a transcendent position in both the international and domestic spheres. Internationally, human rights are seen to be fundamental norms that have a constitutional feature and serve as such internationally and at the domestic level, they complement or reinforce the domestic legal framework. Through a case study of Senegal and Cameroon, the analysis in this article has demonstrated that, that process can be achieved through the practice of conventionnalité. Conventionnalité has the potential to contribute to enhancing the consistency of the domestic human rights system by acting as a defacto judicial review process applying international law as the basis for review. While the domestic constitutions retain their superior position vis-a-vis international human rights law, the latter will serve to ensure that other (subordinate) domestic legislation conform with international human rights law requirements. The effect is that the entire system becomes one that is compliant with generally acceptable human rights standards. That is not to say the system is perfected through the process as that is not the role of any judicial review process. Nevertheless, individuals within the state presumably have access to a wider range of rights which they can assert against the state where domestic legislative provisions impose undue restrictions on them. 


\begin{abstract}
It is acknowledged that the development of this practice in Cameroon and Senegal may not be without difficulty. Nevertheless, the article has argued that some of these difficulties could be overcome through an emboldened judiciary, education and training and a willingness of the subordinate jurisdictions (especially in Cameroon) to follow the decisions of the superior jurisdictions. As the Supreme Court in Cameroon has clearly demonstrated, there is sound constitutional basis for that practice. The courts would be failing to exercise their constitutional powers if they persist in avoiding to recognise the pre-eminent position of international law, intended by the legislator. Whilst Fadou may not be sufficient precondition for the development and entrenchment of the practice, it is by no means a negligible catalyst and may be seen as heralding an evolution in that direction. With respect to Senegal, the position may be a little different but without assuming prescient powers, it is probable that developments in regional constitutional law and increasing regional integration would have some impact on the approach of the Senegalese courts.
\end{abstract}

